\title{
Big4 Versus Non-Big4 Opinion about the Going Concern Assessment: A Survey
}

\author{
Fabrizio Bava ${ }^{1} \&$ Melchior Gromis di Trana ${ }^{1}$ \\ ${ }^{1}$ Department of Management, University of Turin, Turin, Italy \\ Correspondence: Melchior Gromis di Trana, Corso Unione Sovietica 218-bis, 10134 Torino, Italy. E-mail: \\ melchior.gromis@unito.it
}

Received: December 3, 2018

Accepted: January 15, 2019

Online Published: January 25, 2019

doi:10.5539/ijbm.v14n2p87

URL: https://doi.org/10.5539/ijbm.v14n2p87

\begin{abstract}
Going concern (GC) assessment is a central element in the audit process. During the Global Financial Crisis the increasing number of companies receiving a going concern opinion (GCO) has stimulated public interest on this topic. Our study fuels the debate about the financial indicators used in professional practice distinguishing between the big4 and non-big4 auditors' perspectives. Similar studies have been conducted in the past that investigated which financial ratios are the most widely used in practice. However, in 2013 Carson et al stressed the fact that the audit environment is in constant evolution, therefore it is essential to update the evidence. Our results highlight which financial indicators in the auditors' opinion are more effective to assess whether the entity is able to continue as a GC. Our research can be useful first of all for auditors in small and medium entities, but also for dierctors, due to the fact that there is a lack of studies regarding the indicators proposed by ISA 570 , where the attitudes of the big4 and non-big4 are compared.
\end{abstract}

Keywords: Going concern, Financial indicators, ISA 570, Big4

\section{Introduction and Institutional Framework in Italy}

In Italy, the GC principle is governed for not listed companies, by Article 2423-bis of the Civil Code (Principles of Financial Reporting), paragraph 1) which states that "the following principles shall be observed in preparing financial statements: all items shall be accounted for in accordance with the prudence concept and on a going concern basis" (this rule was introduced by Legislative Degree 127 of April 9, 1991). For listed companies, this principle is governed by IAS 1 , Presentation of financial statement.

According to Ferrero (1991), this establishes the principle that the term "financial statements" is to be understood as meaning the financial statements of a firm in an ongoing operation: in other words, of a firm that looks to the future and the "continuation of its business". This is a principle that can be regarded as having priority "because of its determining influence" (Ferrero 1991). When the financial statements cannot be prepared on a GC basis, Capaldo (1998) has emphasized that a tangible or intangible asset which would have a very high value if accounted for under the assumption that the business will continue will have practically no value if the business is expected to be liquidated.

The GC principle "affects all of the assessments made in the financial statements" (Superti Furga 1991), given that in the event of GC uncertainties it is necessary to prepare the statements using criteria other than those that would be used for a viable firm.

It should be emphasized that the Italian financial reporting framework does not always offer clear-cut guidance regarding the operational implications of determining whether or not an entity is a going concern.

Italian standard setters have recently (March 2018) implemented the OIC 11 Revised that analyzes the GC principle. When the Italian framework does not appear to be entirely exhaustive, it is necessary to refer to the international IAS/IFRS accounting and reporting standards.

However, regarding the audit process, according to the Italian Auditing Standards (Italian ISA 570), the auditor is required to consider the appropriateness of the GC assumption in the preparation of the financial statement in the entire auditing process, from the planning to the issue of the opinion.

The extent of this assessment depends on the financial situation of the company. If during the auditing process 
auditors recognize signals which may cast significant doubts on the entity's ability to continue as a GC, auditors must perform additional audit procedures in order to prove the compliance with the Italian GAAP and a more thorough knowledge of the company's performance.

At the end of this evaluation, the auditor should determine in their judgment if a use of the GC assumption is appropriate or inappropriate and if a management is unwilling to make or extend its assessments. If the GC assumption is considered to be appropriate with reasonable assurance, the auditor will issue an unqualified opinion also known as "clean opinion".

In reading the auditing standards, it is not easy to identify the level of uncertainty beyond which management should conclude that there are no realistic prospects for continuing as a going concern. This can often lead to differences with the auditors, who are called upon to evaluate management's actions in situations where the firm is in serious financial distress, and deciding whether the going concern assumption still holds is quite complex. In Italy, an initial analysis of the concept's operational implications took place in 2007 when the CSPR, Italy's joint committee for auditing standards, published Standard 570. In reality, this was a translation of the corresponding international standard, ISA 570. The issue was thus viewed from the standpoint of the auditors' tasks, rather than directly regarding the management's preparation of the financial statements. The Clarified ISAs were then introduced to provide all auditing practioners with a benchmark. A committee set up by CNDCEC, Italy's national board of registered commercial practitioners and accountants translated the Clarified ISAs which were then submitted to the European Union for publication in an EU Regulation. To date, however, the auditing standards have not yet been adopted by the European Commission, therefore standards have had to be set for use in this transition period. These are conventionally known as the "international auditing standards (ISA Italia)", in force since 2015, and approved by the Ministry of the Economy and Finance (General Accounting Office) on December 23, 2014. In July 2017, Italian standard setters implemented the revised version of the ISA 570 for the audit of financial statements dated 2017. The law (Legislative Decree, 39/2010) was also changed to make it compliant with the necessity of auditing standards to incorporate a going concern disclosure in auditor opinion.

The remainder of the paper is organized as follows. In the next section, we examine the literature, then in the third paragraph we develop our hypotheses, discuss the research method and describe the survey. After presenting empirical results and a discussion, the paper ends with a brief conclusion.

\section{Literature}

International evidence suggests that auditors have responded to the financial crisis with a greater attention towards GC issues, as rates of opinions modified for GC uncertainty increased during 2008 in the UK., Australia, and France (Carson et al. 2011), as well as in Italy, where there was a considerable rise in the number of listed companies which obtained a qualified GCO (15 qualified GCOs were issued from 2004 to 2007, against 43 from 2008 to 2011) (Bava \& Gromis 2018/1). Due to this change, the studies aimed at investigating the factors influencing GC assessment have become highly relevant and topical.

In literature we can distinguish between studies which concentrate on the analysis of financial statements items (financial indicators), those which have examined non-financial indicators (including market variables, strategic initiatives and governance characteristics) and those regarding the role of management plans together with auditors (independence, non-audit services, fees, partner's gender, auditor tenure, etc.) and client characteristics (business sector, ownership structure, etc.). The work written by Carson et al. (2013) and Gissel et al. (2010) on this subect is widely recognised.

There have been several attempts to develop statistical models for the prediction of GC matters which may give auditors the necessary to reduce the subjectivity rate in their assesment, and contribute to raising consent regarding the auditor's decision (Carson et al. 2016). The main aim of our research was to focus on the literature oriented towards the identification of indicators that can signal GC problems as well as from a standards on auditing perspective. ISA Italia 570 recognizes a series of circumstances that, individually or collectively, may cast significant doubt on the capability of the entity to continue as a GC. ISA 570, para A.2., classifies those in three main categoires: financial indicators, operating indicators and others.

ISA 570's red flags include the fact that it was impossible to comply with the terms of loan agreements and fixed-term borrowings which were approaching maturity should there be no real prospects of renewal or repayment. According to Chen and Church (1992), for auditors an important indicator of the issuance of a GCO is the presence of default on debt obligations and the approaching need to restructure debt. There are numerous international studies which have highlighted that the size of debt does have an influence on GC decisions. The level of debt has been measured with a number of indicators.

Despite the fact that in the final analysis a lack of cash and liquidity results in a company's bankruptcy, profitability 
is a key factor in GC assessments. The importance attributed to significant operating losses by ISA 570, along with adverse key financial ratios is endorsed by international studies, many of which have stated that it is more probable for auditors to issue GCOs when companies have difficulties with profitability. Profitability is a fundamental condition for generating cash from operations. The capacity of a company in financial distress to receive fresh backing from lenders and investors is dependant on the earnings forecasts. This is due to the fact that it is unlikely that companies expected to continue to produce losses will attract investments (Feng \& Li, 2014). In accordance with the literature (Carson, Fargher, \& Zhang, 2016), the studies dealing with financial indicators are the following (Table 1):

Table 1 - financial indicators

\begin{tabular}{|c|c|}
\hline & Kida 1980; Mutchler 1985; \\
\hline Current assets / Current liabilities & Menon and Schwartz 1987 \\
\hline Interest expense / Earnings before interest and tax & Koh 1991 \\
\hline Cash / Current liabilities & $\begin{array}{l}\text { Kida 1980; Koh and Killough 1990; } \\
\text { Koh 1991; Lennox } 1999\end{array}$ \\
\hline Working capital / Total liabilities & Mutchler 1985 \\
\hline Cash flow from operations / Total liabilities & $\begin{array}{l}\text { Menon and Schwartz 1987; } \\
\text { Raghunandan and Rama } 1995\end{array}$ \\
\hline Market value of equity / Book value of debt & Altman and McGough 1974 \\
\hline Book value of net worth / Book value of debt & Kida 1980 \\
\hline Total long term liabilities / Total assets & Mutchler 1985 \\
\hline Total liabilities / Total assets & Dopuch et al.1987; Raghunandan and Rama 1995 \\
\hline Net income / Total assets & Kida 1980; Mutchler 1985; Dopuch et al.1987 \\
\hline Retained earnings / Total assets & $\begin{array}{l}\text { Altman and McGough 1974; Koh and Killough 1990; } \\
\text { Dopuch et al.1987; Menon and Schwartz } 1987\end{array}$ \\
\hline Earnings before interest and taxes / Total assets & Altman and McGough 1974 \\
\hline Net income before tax / Net sales & Mutchler 1985 \\
\hline Current and/or recurring losses & Dopuch et al.1987; Lee et al. 2005 \\
\hline
\end{tabular}

Other studies have focused on indicators deemed by auditors to be the most sensitive in their professional practice. In particular, questionnaires were completed enabling Mutchler (1984) and LaSalle \& Anandarajan (1996) to verify the importance assigned by auditors to the different financial ratios in the GC assessment. The main indicators identified by these studies are (Table 2):

Table 2. Financial indicators

\begin{tabular}{c}
\hline Cash flow from operations/total debt \\
Current assets /current liabilities \\
Net worth/total debt \\
Total debt/total assets \\
Total liabilities/total assets \\
\hline Net worth/total liabilities \\
Cash flows from operations/total liabilities \\
Current assets/current liabilities \\
Total liabilities/total assets \\
Change in net worth/total liabilities
\end{tabular}


As stated by Carson et al. 2013, studies on this topic may be outdated due to the constant changes in the audit environment. Thus evidence concerning the variables that auditors take into account for the GC assessment must be "refreshed".

In this way, in a previous work (Bava \& Gromis di Trana, 2018) a questionnaire was issued to obtain more current evidence from auditors. At the same time a comparison was introduced between auditors and academic experts' opinions. The present research focuses solely on the auditors' perspective, comparing the responses of the big4 and non-big4.

\section{Research Method}

The research has based the comparison on opinions collected by an online questionnaire issued to auditor partners of the big4 and non-big4 firms. Furthermore, in order to bring the literature up to date, the questions of this survey are based on the contents found in the current auditing standard ISA 570.

The first research question to be asked is:

RQ1. Of all the factors that question the ability of an entity to continue as a GC listed in ISA 570, which do the Italian big4 and non-big 4 auditors consider to be the most important?

Some factors that must be considered when assessing the entity's capacity to continue as a GC are listed by the auditing standard (ISA 570). The listing thus provided is merely an example, therefore it is not all-inclusive. The goal of the question is to identify which type of indicator should be observed the most carefully in order to assess the presence of the GC assumption. At the same time, the aim is to collect suggestions from auditors regarding any other indicators which ISA 570 may not have considered. The respondents choosing financial indicators are expected to predominate, in keeping with the international literature that pays great attention to them and presents evidence regarding the relationship between financial indicators and the GC issue.

Therefore the second research question is:

RQ2. According to the big4 and non-big4 auditors, which of the most commonly used financial indicators are deemed to be the most sensitive when assessing a GCO?

On this point some general financial indicators have been put forward by the auditing standard (ISA 570), which have been thoroughly analysed to identify more specific and synthetic financial ratios. Our paper has investigated the opinion of Italian auditor partners regarding these indicators and an attempt to identify more relevant indicators concerning GC assessment has been made. For this reason, the survey includes also indicators that are not contemplated by the auditing standard. Moreover, to collect additional ratios or suggestions, the questionnaire structure provides open spaces for comments so that the interviewees can add any comments or personal evaluations. Responses to RQ2 can help, from an operating perspective, to apply the indications of ISA Italia 570 which may be deemed to be too generic.

\subsection{The Survey}

The investigation was conducted by means of an online questionnaire, which was created and administered using Survey Monkey ${ }^{\circledR}$ software, collecting the remarks of auditors.

Participants received an email with the link to access the questionnaire. Participants could only fill it in once, as the software checks the TCP/IP. The questionnaire consisted of 11 questions and on average respondents spent 9 minutes filling it in.

Participants were sent the presentation of the research and the reminders three times, at two-weekly intervals.

In order to increase the retention rate a dropdown list to rank indicators was used, differently from prior studies, where respondents gave each indicator a score based on its importance, (for example, on a scale of 1 to 5 , where 1 is least important and 5 is most important). This choice derives from the fact that all of the indicators listed in the auditing standard are considered to be are important. Thus the indicators must simply be ranked in a hierarchy and there is no need to assign a specific score to each one. Consequently it is impossible for the same score to be assigned to more than one indicator, skewing the ranking upwards. As can be seen, the indicators used are taken directly from the auditing standard. After the section a question is asked on the so-called mitigating factors indicated in the auditing standard and there is a final, open-ended question asking the respondents to go over their answers to the previous questions, stating the indicators they believe should be adopted in $\mathrm{GC}$ assessments.

The respondents were all auditor partners from the Big4 and a further 246 Italian audit firms. The number of emails sent and the retention rate are summarized in table 3 below. 
Table 3. Emails sent

\begin{tabular}{lrrc}
\hline & Addressees & Responses & \% \\
\hline Big4 & 191 & 41 & 21,5 \\
No-Big4 & 364 & 50 & 13,4 \\
Total Auditors & 555 & 91 & 16,4 \\
\hline
\end{tabular}

Neuman (2000) stated that response rates are a significant factor. This is due to the fact that a low response rate may lead to bias, thus compromising the validity of the research. Extreme caution must be taken before the results are generalized and analysed. There was a response rate of $21.5 \%$ and $13.4 \%$ which in our case is adequate, especially as Neuman (2000) claimed the response rate should be in a range of 10-50\%. The results of this work can therefore be safely said to be generally valid. Although all the answers were anonymous (and respondents were told this), the auditor's concern that this paper had the intention of evaluating the quality of their GC assessment and of their audit firms influenced the retention rate.

\section{Results}

In this section we show the statistics concerning the responses for each question.

Q1) Which of the events or conditions that might raise questions on GC assumption listed in ISA570 do you consider to be the most significant?

Table 4. Result Q1

\begin{tabular}{lccrr}
\hline & Big4 & \% & Non-Big4 & \% \\
\hline Financial & 37 & $90 \%$ & 41 & $82 \%$ \\
Operating & 4 & $10 \%$ & 6 & $12 \%$ \\
Other & 0 & $0 \%$ & 3 & $6 \%$ \\
Total & 41 & $100 \%$ & 50 & $100 \%$ \\
No answer & 0 & $0 \%$ & 0 & $0 \%$ \\
\hline
\end{tabular}

As expected, respondents selecting financial indicators (economic, financial and equity difficulties) predominated (respondents could select only one of the three answer options). There is a great deal of literature which examines the main indicators that point to GC uncertainties, and this result was in keeping with it. Accoridng to Carson et al. (2013), "major insight from such research is that publicly available financial statement information is an important factor associated with the auditor's decision to issue a GCO”. The greater importance of financial indicators according to the auditors was to be expected due to the fact that in professional practice, it is easier to estimate these indicators and they are also less subjective compared to the operating one (difficulties with management, labor, markets).

Q2) Of the following financial indicators which do you consider to be the most important?

Respondents were requested to choose their top five indicators and put them in order of relevance. The table below shows the frequency with which a number of indicators were included in the top five. The auditing standard proposes the first 11 indicators, whereas a further three (12-13-14) are circustances which are at times considered in professional practice. 
Table 5. Q2 results

\begin{tabular}{|c|c|c|c|c|c|}
\hline & & Big4 & $\%$ & Non-Big4 & $\%$ \\
\hline 1 & Net liability or net current liability position & 32 & 78.05 & 36 & 49.36 \\
\hline 2 & $\begin{array}{l}\text { Fixed term borrowings approaching maturity } \\
\text { without realistic prospects of renewal or } \\
\text { repayment; or excessive reliance on short } \\
\text { term borrowings to finance long term }\end{array}$ & 33 & 80.49 & 30 & 44.87 \\
\hline & assets. & & & & \\
\hline 3 & $\begin{array}{l}\text { Indications of withdrawal of financial } \\
\text { support by creditors. }\end{array}$ & 23 & 56.10 & 31 & 72.00 \\
\hline 4 & $\begin{array}{l}\text { Negative operating cash flows indicated by } \\
\text { historical or prospective financial statements }\end{array}$ & 17 & 41.46 & 35 & 60.00 \\
\hline 5 & Adverse key financial ratios. & 20 & 48,78 & 29 & 62.00 \\
\hline 6 & $\begin{array}{l}\text { Substantial operating losses or significant } \\
\text { deterioration in the value of assets used to } \\
\text { generate cash flows }\end{array}$ & 23 & 56.10 & 32 & 70.00 \\
\hline 7 & Arrears or discontinuance of dividends & 6 & 14.63 & 8 & 58.00 \\
\hline 8 & Inability to pay creditors on due dates & 27 & 65.85 & 38 & 64.00 \\
\hline 9 & $\begin{array}{l}\text { Inability to comply with the terms of loan } \\
\text { agreements }\end{array}$ & 20 & 48.78 & 16 & 16.00 \\
\hline 10 & $\begin{array}{l}\text { Change from credit to cash - on } \\
\qquad- \text { delivery transactions with suppliers }\end{array}$ & 7 & 17.07 & 11 & 76.00 \\
\hline 11 & $\begin{array}{l}\text { Inability to obtain financing for essential } \\
\text { new product development or other essential } \\
\text { investments }\end{array}$ & 10 & 24.39 & 16 & 32.00 \\
\hline 12 & $\begin{array}{l}\text { Negative operating cash flows in cash flow } \\
\text { statement }\end{array}$ & 10 & 24.39 & 20 & 40.00 \\
\hline 13 & $\begin{array}{l}\text { Negative investment cash flow in cash flow } \\
\text { statement }\end{array}$ & 5 & 12.20 & 11 & 22.00 \\
\hline \multirow[t]{3}{*}{14} & $\begin{array}{l}\text { Excessive outlays of financial resources } \\
\text { within the group }\end{array}$ & 5 & 12.20 & 13 & 26.00 \\
\hline & Responses & 38 & $92.68 \%$ & 50 & $100.00 \%$ \\
\hline & No answer & 3 & $7.32 \%$ & $\mathbf{0}$ & $0 \%$ \\
\hline
\end{tabular}

The indicators which were most frequently selected as being among the top five were numbers $2,1,8,3$ and 6 for the big4, and 8, 1, 4, 6 and 3 for the non-big4. Four of the top five selected by the big4 parnes are the same as those selected by non-big4 partners. The indicators chosen were then ranked according to the score received, with 5 being the most important and 1 being the least. Any indicators which failed to be chosen received a score of 0 . 
Table 6. Q2 ranking

\begin{tabular}{|c|c|c|c|c|c|c|}
\hline Big4 & Non-big4 & & Big4 & Mean & Non-big4 & Mean \\
\hline 1 & 3 & $\begin{array}{l}\text { Fixed term borrowings } \\
\text { approaching maturity without } \\
\text { realistic prospects of } \\
\text { renewal or repayment; } \\
\text { or excessive reliance } \\
\text { on short term borrowings } \\
\text { to finance long term assets. }\end{array}$ & 116 & 3.74 & 98 & 3.63 \\
\hline 2 & 1 & $\begin{array}{c}\text { Net liability or net } \\
\text { current liability position }\end{array}$ & 113 & 3.40 & 150 & 4.41 \\
\hline 3 & 5 & $\begin{array}{c}\text { Inability to pay creditors } \\
\text { on due dates }\end{array}$ & 70 & 2.80 & 74 & 2.47 \\
\hline 4 & 4 & $\begin{array}{l}\text { Indications of withdrawal } \\
\text { of financial support } \\
\text { by creditors. }\end{array}$ & 58 & 3.22 & 83 & 2.68 \\
\hline 5 & - & $\begin{array}{l}\text { Substantial operating losses } \\
\text { or significant deterioration } \\
\text { in the value of assets used } \\
\text { to generate cash flows }\end{array}$ & 49 & 2.45 & - & - \\
\hline - & 2 & $\begin{array}{l}\text { Negative operating cash } \\
\text { flows indicated by historical } \\
\text { or prospective financial } \\
\text { statements }\end{array}$ & - & - & 100 & 3.03 \\
\hline
\end{tabular}

Using this scoring system, it can be observed that two out of three indicators of the top big4 auditors' rankings are the same as those in the non-big4' top three. These indicators, which are the "net liability or net current liability position" and "Fixed-term borrowings approaching maturity without realistic prospects of renewal or repayment", are signals of potential future insolvency.

Q3) When making a GC assessment, what is the percentage weight you attribute to the forecasts made in management plans, and what is the weight you attribute to the information disclosed in the financial statements?

Table 7. Q3 results

\begin{tabular}{lcccc}
\hline & Big4 & $\mathbf{\%}$ & Non-Big4 & \% \\
\hline Approved financial statements & & 43.95 & & 53,10 \\
Management plans/budgets & & 56.05 & & 46.90 \\
Responses & $\mathbf{3 8}$ & $\mathbf{9 2 . 6 8 \%}$ & $\mathbf{5 0}$ & $\mathbf{1 0 0 . 0 0 \%}$ \\
No answer & $\mathbf{3}$ & $\mathbf{7 . 3 2 \%}$ & $\mathbf{0}$ & $\mathbf{0 . 0 0 \%}$ \\
\hline
\end{tabular}

Respondents were requested to attribute a percentage importance to both options, so that the total would come to $100 \%$. Greater relevance was assigned to the business plan by Big4 partners (56.05\%), whereas non-Big4 partners accounted for $46.90 \%$.

The high number of non-Big4 respondents that believe approved financial statements to be more important than plans, as well as Big4, seems to be more oriented towards attributing greater weight to management plans. This might be surprising, because GC assessments must be necessarily based on the future. Therefore a greater reliance on forecasts would be expected. The explanation for this finding is that a level of uncertainty is an intrinsic part of forecasts and plans, and this often undermines their reliability. This is especially true in small and medium-sized firms where non-Big4 auditors are predominant.

According to Feng and Li (2014), auditors of stressed firms are skeptical of management forecasts, because they often consider them to be over-optimistic (Frost 1997, Koch 2002).

Q4) Which of the following indicators taken from reliable and feasible management plans/budgets do you consider to be the most important when making a GC assessment? 
Table 8. Plans/budgets ratios

\begin{tabular}{ccrcr}
\hline & Big4 & \multicolumn{1}{c}{$\%$} & Non-Big4 & \% \\
\hline Equity / Total debt (i.e., NE + NFP) & 16 & $42.11 \%$ & 18 & $36 \%$ \\
Net Financial Position / EBITDA & 25 & $65.79 \%$ & 24 & $48 \%$ \\
Financial expenses / Revenues & 6 & $15.79 \%$ & 10 & $20 \%$ \\
EBITD A / Financial expenses & 23 & $60.53 \%$ & 14 & $28 \%$ \\
EBIT / Financial expenses & 2 & $5.26 \%$ & 16 & $32 \%$ \\
ROI < ROD (average cost of debt) & 4 & $10.53 \%$ & 8 & $16 \%$ \\
$\quad$ Cash flow & 32 & $84.21 \%$ & 40 & $80 \%$ \\
Other (specify) & 1 & $2.63 \%$ & 1 & $2 \%$ \\
Responses & $\mathbf{3 8}$ & $\mathbf{9 2 . 6 8 \%}$ & $\mathbf{5 0}$ & $\mathbf{1 0 0 . 0 0 \%}$ \\
No answer & $\mathbf{3}$ & $\mathbf{7 . 3 2 \%}$ & $\mathbf{0}$ & $\mathbf{0 . 0 0 \%}$ \\
\hline
\end{tabular}

Respondents had the possibility to make up to three choices. Although the indicators proposed in this question are not suggested by the auditing standard, they are extensively used by both auditing firms and banks so as to assess the sustainability of a firm's debt (Devalle \& Pisoni 2016). With regards to prospective documents respondents have emphasized the central role attributed to cash flow, as can be seen by the choice of the Cash Flow indicator and of the Net Financial Position/EBITDA ratio. But in order to gain support from lenders and investors, firms must also pay attention to the ratio between $\mathrm{NE}$ and the total debt represented by equity and the net financial position.

Only a handful of auditors specified other additional ratios, which means that the suggested ratios were considered to be the most important. Note that the ranking of the first two indicators is the same for the BIG4 and Non-BIG4 Auditors.

Q5) Which of the following ratios taken from financial statemetns do you consider to be most useful when making a $\mathrm{GC}$ assessment?

Table 9. Financial statement ratio

\begin{tabular}{ccccc}
\hline & Big4 & $\mathbf{\%}$ & Non-Big4 & $\mathbf{\%}$ \\
\hline Equity / Total debt (i.e., NE + debt) & 24 & $63,16 \%$ & 30 & $60,00 \%$ \\
Net Financial Position / EBITDA & 31 & $81,58 \%$ & 37 & $74,00 \%$ \\
Financial expenses / Revenues & 8 & $21,05 \%$ & 20 & $40,00 \%$ \\
EBITDA / Financial expenses & 24 & $63,16 \%$ & 16 & $32,00 \%$ \\
EBIT / Financial expenses & 10 & $26,32 \%$ & 13 & $26,00 \%$ \\
ROI < ROD (average cost of debt) & 5 & $13,16 \%$ & 24 & $48,00 \%$ \\
Other (specify) & 2 & $5,26 \%$ & 1 & $2,00 \%$ \\
Responses & $\mathbf{3 8}$ & $\mathbf{9 2 . 6 8 \%}$ & $\mathbf{1 4 5}$ & $\mathbf{1 0 0 . 0 0 \%}$ \\
No answer & $\mathbf{3}$ & $\mathbf{7 . 3 2 \%}$ & $\mathbf{4 5}$ & $\mathbf{0 . 0 0 \%}$ \\
\hline
\end{tabular}

As for the previous question, respondents could select up to 3 choices. Big4 and the non-Big4 partners totally agree on the selection of the first two ratios, which are / EBITDA and NE/Debt. Despite being synthetic, they are particularly effective in signaling any problems an entity may have in these areas. A higher score was attributed to EBITDA/Fin.Exp. than EBIT/Fin.Exp. and Fin.Exp./Revenues. This is reasonable, due to the fact that EBITDA is more reliable than EBIT as a measure of a firm's ability to produce cash, and the information value of the weight of financial expenses on revenue is limited because revenues do not represent a margin. Therefore the use of this indicator presupposes that the firm's revenues is able to maintain a certain level of financial expenses. However, this is not the case for all firms with a very low operating income.

The next question refers to the relevance attributed to "global ratios" resulting from the application of statistical models which link multiple indicators or other company variables.

Q6) Numerous statistical models have been created in order to forecast the likelihood that an entity will fail over the years (e.g., Z-score). Do you use statistical models of this kind when making a GC assessment? 
Table 10. Q6 results

\begin{tabular}{lcccc}
\hline & Big4 & \% & Non-Big4 & \% \\
\hline Yes & 4 & $10.53 \%$ & 8 & $16 \%$ \\
No & 34 & $89.47 \%$ & 42 & $84 \%$ \\
Responses & $\mathbf{3 8}$ & $\mathbf{9 2 . 6 8 \%}$ & $\mathbf{5 0}$ & $\mathbf{1 0 0 . 0 0 \%}$ \\
No answer & $\mathbf{3}$ & $\mathbf{7 . 3 2 \%}$ & $\mathbf{0}$ & $\mathbf{0 . 0 0 \%}$ \\
\hline
\end{tabular}

These forecasting models have been proven to be relatively reliable. However they are not used to any great extent in auditing practice as can be confirmed by the auditors (Big4 and non-Big4).

Q7) What statistical model do you consider to be the most important?

Table 11. Q7 results

\begin{tabular}{cllll}
\hline & Big4 & $\mathbf{\%}$ & Non-Big4 & \% \\
\hline Altman Z - score & 1 & $25 \%$ & 4 & $50 \%$ \\
Auditing firm internal model & 3 & $75 \%$ & 2 & $25 \%$ \\
Other indicators & 0 & $0 \%$ & 2 & $25 \%$ \\
Responses & $\mathbf{4}$ & $\mathbf{9 . 7 6 \%}$ & $\mathbf{8}$ & $\mathbf{1 6 . 0 0 \%}$ \\
No answer & $\mathbf{3 7}$ & $\mathbf{9 0 . 2 4 \%}$ & $\mathbf{4 2}$ & $\mathbf{8 4 . 0 0 \%}$ \\
\hline
\end{tabular}

The Big4 can have an internal model, which explains the results even though the most common model is the Altman Z-score.

Q8) If you replied "no" to question Q8) give reasons for your decision.

Respondents were free to express their opinions as this was an open-ended question.

Table $12-\mathrm{Q} 8$ results

\begin{tabular}{lcccc}
\hline & Big4 & $\%$ & Non-Big4 & $\%$ \\
\hline Responses & 27 & $65.85 \%$ & 15 & $30.00 \%$ \\
No answer & 14 & $34.15 \%$ & 35 & $70.00 \%$ \\
\hline
\end{tabular}

The main reasons these tools are used so little in professional practice according to the respondents lies in the following:

- they do not apply to the prospective situation and the company's prospects;

- they are not appropriate for the specific nature of the individual firms;

- $\quad$ they are useful, but I don't use them;

- $\quad$ they are over-simplified, uncertain, distort reality and can be manipulated.

Q9) Do you think that the recently introduced requirement to include a cash flow statement with the statutory financial statements can be an important change in making going concern assessments?

Table 13. 9 results

\begin{tabular}{lcccc}
\hline & Big4 & \% & Non-Big4 & \% \\
\hline Yes & 25 & 65.79 & 35 & 70,00 \\
No & 13 & 34.21 & 15 & 30.00 \\
Responses & $\mathbf{3 8}$ & $\mathbf{9 2 . 6 8 \%}$ & $\mathbf{5 0}$ & $\mathbf{1 0 0 . 0 0 \%}$ \\
No answer & $\mathbf{3}$ & $\mathbf{7 . 3 2 \%}$ & $\mathbf{0}$ & $\mathbf{0 . 0 0 \%}$ \\
\hline
\end{tabular}

Question 9 reflects the fact that Italian legislation has recently established that entities subject to the extensive disclosure requirements of the Civil Code must also prepare a cash flow statement.

The cash flows statement is very important to assess the entity's ability to continue as a going concern (Eman Hanini \& Modar Abdullatif, 2013). 
As expected, the results underscore the importance of this new disclosure.

Q10) In your opinion, does this new statement affect going concern assessments?

Table 14. Q10 results

\begin{tabular}{lcc}
\hline & Responses & $\%$ \\
\hline Responses & 44 & $48.35 \%$ \\
No answer & 47 & $51.64 \%$ \\
\hline
\end{tabular}

The main reasons why the cash flow statement affects GC assessments according to the respondents are the following:

- $\quad$ it provides more complete information by detailing cash flows;

- it makes it easier to understand company performance trends.

Some respondents underlined that it had already been compulsory in the past.

Q11) In view of your answers to the foregoing questions, can you tell us which indicators you rely on most in your going concern assessments, and briefly state why you favor them?

Table 15. Q11 results

\begin{tabular}{lcc}
\hline & Responses & \% \\
\hline Responses & 44 & $48.35 \%$ \\
No answer & 47 & $51.64 \%$ \\
\hline
\end{tabular}

Respondents' comments are summarized below.

Table 16. Q11 results

\begin{tabular}{l}
\hline Debt sustainability \\
\hline Net Financial Position/ EBITDA \\
EBITDA / Financial expenses \\
Net Financial Position/NE \\
Free cash flow/ financial debt \\
Forecast data \\
Cash flow forecasts \\
Management plans \\
Financial budget credibility \\
Financial magnitudes \\
Cash flow from operations \\
Net Financial Position \\
Ability to generate cash flow \\
Working capital \\
Financial debt / NE \\
Non-current assets / NE + consolidated debt \\
Current assets / Current liabilities \\
Change in working capital / Revenues \\
Working capital / Revenues \\
Cash flow from operations / Current debt \\
Change in working debt \\
Working capital / Total assets \\
Economic indicators \\
EBITDA \\
ROI \\
ROE \\
ROI-ROD \\
ROI - Interest payable \\
ROS \\
Operating income \\
Revenues / Total assets \\
\hline
\end{tabular}




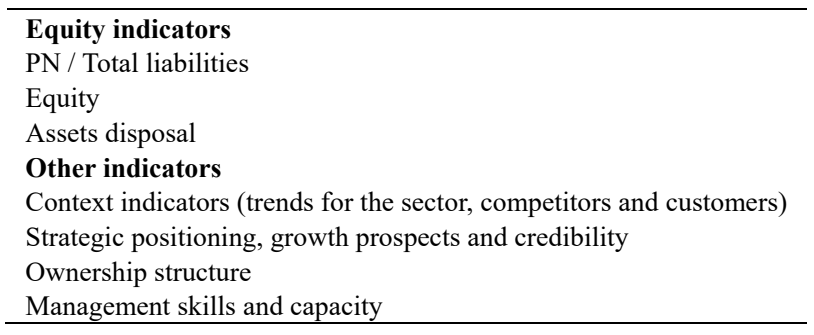

\section{Conclusions and Future Research}

We have investigated the auditors' big4 and non-big4' opinions on which the most important financial indicators are proposed by the auditing standard setter (Italia ISA 570). Then we expanded our investigation to discover which were the most sensitive ratios assesed on financial statements by professional auditors. The results are in keeping with past studies on this topic based on surveys and it expands and refreshes the results. As expected, the big4 perspective is aligned with the non-big4 one, confirming the validity of the suggestions collected. Our work is not aimed at creating a hierarchy that can be applied in general terms, as this cannot be achieved directly due to the complexity of GC issues. However, this study highlights the indicators deemed to be especially effective in in signaling GC risks.

Answering RQ1, we have contributed to improving the literature, extending an initial investigation (Bava \& Gromis, 2018 b) comparing the opinion of the Italian big4 and non-big4 auditors on the relevant varibles used in the GC assessment. The next step was to identify a relevance ranking. It should be pointed out that the international ISA 570 provides a not all-inclusive list of events or conditions that may question the entity's capacity to carry on as a going concern without a classification based on relevance. The "adverse key financial ratio" is one of the indicators that Italia ISA 570 proposes. However, there is no specification as to which ratios should be considered when making this kind of assessment.

As a response to RQ2, our studies have identified which specific financial ratios are deemed to be the most relelvant when making a GC assessment.

It must be said that this study does not, and indeed would not be able to identify the best single indicator capable of signaling the incapacity of a company to continue under the GC assumption. The reason for this lies in the complexity of the assessment, consequently, it cannot be solely limited to the application of synthetic indicators. This point was also raised by the auditors involved in the questionnaire. Concerning the indicators which are considered to the most significant in GC assessments by the auditors, the findings are fundamentally in keeping with previous literature and auditor practice. The main aspect of our work, which highlights the most effective indicators and ratios in order to assess an entity's ability to carry on as a going concern, may be useful both for directors and auditors, especially when they are operating in small and medium entities. Indeed in Italy, especially with regards to the small entities, auditors are usually not partners of specialized auditing firms, but are merely professionals who possess limited auditing skills, operating principally in the field of taxation issues.

\section{References}

Altman, E., \& McGough, T. (1974). Evaluation of a company as a going concern. Journal of Accountancy, $138(6), 50-57$.

Bava, F., Gromis, D. T. (2018). Going concern emphasis of matter and accuracy of audit opinion: Italian evidence. International Business Management, 12(3). https://doi.org/10.3923/ibm.2018.292.298

Bava, F., Gromis, D. T. (2018). ISA 570: Italian Auditors' and Academics' Perceptions of the Going Concern Opinion. Australian Accounting Review. https://doi.org/10.1111/auar.12238

Capaldo, P. (1998). Reddito, capitale e bilancio di esercizio, Giuffrè editore, Milano.

Carson, E., Fargher, N., \& Zhang, Y. (2016). Trends in Auditor Reporting in Australia: A Synthesis and Opportunities for Research. Australian Accounting Review, 26, 226-242. https://doi.org/10.1111/auar.12124

Carson, E., Fargher, N., Geiger, M., Lennox, C., Raghunandan, K., \& Willekens, M. (2013). Audit Reporting for Going-Concern Uncertainty: A Research Synthesis. AUDITING: A Journal of Practice \& Theory, 32(1), 353-384. https://doi.org/10.2308/ajpt-50324

Chen, K. W., \& Church, B. K. (1992). Default on Debt Obligations and the Issuance of Going-Concern Opinions. Auditing: A Journal of Practice and Theory 11 (Fall): 30-49. 
Devalle, A., \& Pisoni, P. (2016). Analisi finanziaria - Giuffrè.

Dopuch, N., Holthausen, R. W., \& Leftwich, R. W. (1987). Predicting audit qualifications with financial and market variables. The Accounting Review, 62(3), 431-454.

Feng, M., \& Li, C. (2014). Are Auditors Professionally Skeptical? Evidence from Auditors' Going-Concern Opinions and Management Earnings Forecasts. Journal of Accounting Research, 52, 1061-1085. https://doi.org/10.1111/1475-679X.12064

Ferrero, G. (1991). I complementari principi della "chiarezza", della verità e della "correttezza" nella redazione del bilancio d'esercizio, Giuffrè, Milano.

Frost, C. (1997). Disclosure Policy Choices of UK Firms Receiving Modified Audit Reports. Journal of Accounting and Economics, 23, 163-187.

Gissel, J., Robertson, J., Stefaniak, C. M. (2010). Formation and consequences of going-concern opinions: A review of the literature. Journal of Accounting Literature, 29, 59-141.

Koch, A. (2002). Financial Distress and the Credibility of Management Earnings Forecasts. Working paper, University of Virginia, 2002. Retrieved from https://papers.ssrn.com/sol3/papers.cfm?abstract_id $=415580$

Kida, T. (1980). An investigation into auditors' continuity and related qualification judgments. Journal of Accounting Research, 18, 506-523.

Koh, H. C. (1991). Model predictions and auditor assessments of going concern status. Accounting and Business Research, 21(84), 331-338.

Koh, H. C., \& Killough, L. (1990). The use of multiple discriminate analyses in the assessment of the going-concern status of an audit client. Journal of Business Finance and Accounting, 17(2), 179-192.

LaSalle, R., \& Anandarajan, A. (1996). Auditors' views on the type of audit report issued to entities with going concern uncertainties. Accounting Horizons, 10(2), 51-72.

Lee, P., Jiang, W., \& Anandarajan, A. (2005). Going concern report modeling: A study of factors influencing the auditor's decision. Journal of Forensic Accounting, 6(1), 55-76.

Lennox, C. (1999). The accuracy and incremental information content of audit reports in predicting bankruptcy. Journal of Business, Finance and Accounting, 26(5-6), 757-778.

Menon, K., \& Schwartz, K. (1987). An empirical investigation of audit qualification decisions in the presence of going concern uncertainties. Contemporary Accounting Research, 3, 302-315.

Mutchler, J. F. (1984). Auditors' perceptions of the going-concern opinion decision. Auditing: A Journal of Practice \& Theory, 3, 17-29.

Mutchler, J. F. (1985). A multivariate analysis of the auditor's going-concern opinion decision. Journal of Accounting Research, 23(2), 668-682.

Neuman, W. L. (2000). Social research methods: Qualitative and quantitative approaches (4th ed.). Needham Heights: Allyn and Bacon.

Raghunandan, K., \& Rama, D. V. (1995). Audit reports for companies in financial distress: Before and after SAS No. 59. Auditing: A Journal of Practice \& Theory, 14(1), 50-63.

Superti, F. F. (1991). Il bilancio di esercizio italiano secondo la normativa europea.

\section{Copyrights}

Copyright for this article is retained by the author(s), with first publication rights granted to the journal.

This is an open-access article distributed under the terms and conditions of the Creative Commons Attribution license (http://creativecommons.org/licenses/by/4.0/). 